\title{
PUISI SUFI A. MUSTOFA BISRI
}

\author{
Abdul Wachid B.S. \\ Institut Agama Islam Negeri Purwokerto \\ Jl. A. Yani 40-A (+62-281) -635624 Purwokerto 53126 \\ E-mail: achidbs99@yahoo.com \\ HP. +62-817271450
}

Abstrak: This article reveals A. Mustofa Bisri's thoughts implicitly found in his poems. As a scholar in Nahdlatul Ulama, he has an attractive thought; he is a scholar who writes literary works. To interpret his poems needs attention to the referential meaning as a means to get into the dimension of language and reality. At symbolic level, poems are understood as a part of life expression referred to the root of knowledge. From such a method, it can be revealed some important points: first, the poems written by A. Mustofa Bisri are expressed in simple language as self-manifestation of the writer and his works. The simplicity of language needs deeper understanding to know the writer's perspective and dimension. Second, there is a similarity betweem A. Mustofa Bisri's and Sufism poems themed love and yearning to Allah.

Keywords: poem, Sufi, A. Mustofa Bisri, symbol, love dan yearning.

Abstrak: Tulisan ini berusaha mengungkap pemikiran penting A. Mustofa Bisri yang tersirat di dalam puisi-puisinya. Ia sebagai ulama di kalangan Nahdlatul Ulama memiliki pemikiran yang menarik, yakni sebagai kiai yang menulis karya sastra. Untuk memaknakan puisi-puisi yang ditulis oleh A. Mustofa Bisri, dibutuhkan perhatian pada arti referensial sebagai jalan untuk memasuki ranah bahasa dan realitas. Pada tataran simbolik, berusaha memahami puisi sebagai bagian dari ekspresi kehidupan yang dirujuk sampai pada akar pengetahuan. Dari metode seperti itu, dapat ditemukan beberapa hal penting; pertama, puisi yang ditulis oleh A. Mustofa Bisri diungkapkan dengan bahasa sederhana sebagai manifestasi diri dan ciptaanya. Kesederhanaan bahasa tersebut membutuhkan pemahaman yang lebih mendalam terkait dengan wawasan dan dimensi dari penyair. Kedua, ada kesamaan tematik puisi A. Mustofa Bisri dengan puisi tradisi sufi yang bertema cinta dan kerinduan kepada Allah.

Kata Kunci: Puisi, Sufi, A. Mustofa Bisri, Simbol, Cinta dan Rindu. 


\section{A. Pendahuluan}

A. Mustofa Bisri termasuk ulama penting di kalangan Nahdlatul Ulama (NU). Ia pernah menolak secara halus saat dicalonkan menjadi Ketua Pengurus Besar Nahdlatul Ulama, juga menolak saat dicalonkan menjadi Ketua Umum Partai Kebangkitan Bangsa (PKB). Ia lebih memilih tetap berada di tengah umat secara langsung, dengan mengasuh santri di Pondok Pesantren peninggalan ayahnya, Raudlotut Tholibien, Rembang, di samping terus produktif menulis masalah sosial budaya di berbagai media massa, juga menjadi pembicara di berbagai seminar dan pengajian akbar.

Buku puisi Gandrung dengan label "sajak-sajak cinta" di bagian cover depan buku ini mengundang perhatian orang, apalagi desain cover dan grafis, ilustrasi gambar cover, dan di setiap halaman sajak, semua itu seakan menyaran seperti catatan harian seorang pemuda atau gadis yang sedang dimabuk cinta. Dalam buku sajak-sajak cinta Gandrung, pembaca akan banyak menjumpai ungkapan-ungkapan dan perilaku orang yang sedang "gandrung" (istilah dari bahasa Jawa), yaitu cinta kepayang seorang laki-laki kepada perempuan.

Memang, puisi merupakan suatu ungkapan bahasa yang memiliki makna lain, ada ketaklangsungan ekspresi (Riffaterre, 1978 : 1). Dengan demikian, sebagaimana dinyatakan Rene Wellek (1990:15) bahwa bahasa sastra (terutama puisi) penuh ambiguitas, konotatif, bukan sekadar referensial yang mengacu pada satu hal tertentu. Dengan begitu, bahasa puisi bermakna ganda (polyinterpretable). Oleh sebab itu, menjadi dimungkinkan pembaca Gandrung memiliki tafsir (interpretasi) yang berlainan satu dengan lainnya sekalipun bahasa sajak yang digunakan oleh penyairnya sudah plastis, dan metaforanya menyarankan bahasa sajak yang terang. Berbagai simbol dalam sajak-sajak cinta Gandrung, memang mencitrakan percintaan lelaki dan perempuan pada tataran arti (meaning), tetapi pada tataran makna (significance) sajak secara ut uh hal itu belum tentu demikian. Hal itu sebab dalam sajak-sajak cinta Gandrung banyak tersedia simbol yang dapat dicari referensi tradisi estetik dan etiknya kepada perpuisian yang ditulis oleh para sufi-penyair.

Dengan begitu, di saat pembaca membaca dan menilai sajak-sajak cinta Gandrung ini dimungkinkan terjadi perbedaan tafsir (interpretasi) sebab mencitrakan hubungan cinta lelaki dan perempuan. Dalam istilah Erich Fromm di bukunya The Art of Loving (1956, Terj. 2002), hubungan cinta lelaki dan perempuan ini disebutnya sebagai cinta erotik.

Masalah yang kemudian muncul, apa dan bagaimana pencitraan cinta erotik itu menjadi fenomena perpuisian Gandrung karya A. Mustofa Bisri? 
Mengapa pencitraan cinta erotik itu menjadi pilihan ekspresi perpuisiannya? Untuk menjawab persoalan ini, sebelumnya perlu diberi gambaran tentang tradisi pencitraan cinta erotik dalam perpuisian sufisme agar menjadi perbandingan sekaligus ancang-ancang untuk menilai sajak-sajak cinta Gandrung. Kemudian, perlu dianalisis bahasa sajak-sajak cinta Gandrung, yang difokuskan pada citraan kaitannya dengan penggunaan metafora, tentang apa, bagaimana, dan mengapa digunakan pencitraan cinta erotik itu.

Selanjutnya, apa, bagaimana, dan mengapa pencitraan cinta erotik sebagai estetika puisi itu pemaknaannya berhubungan dengan etika tasawuf? Hal tersebut disinyalir bahwa konsep cinta dalam sajak-sajak cinta Gandrung merupakan tingkatan ruhani (maqam), yang dalam tradisi sufisme disebut cinta Ilahiah (mahabbah). Tentu saja, asumsi tersebut akan menempatkan teks cinta sebagai medan pertempuran teks, yang memiliki konteks dengan teks cinta yang melatarinya, dan kontekstualisasi di dalam sajak-sajak cinta Gandrung.

\section{B. Puisi dan Penafsiran}

Hal yang penting dalam penafsiran puisi ialah puisi merupakan tindak pemakaian bahasa yang "diindahkan". Bahasa yang "diindahkan" dalam puisi jelas memiliki perhitungan sendiri yang dilakukan oleh penyair: pertama sebentuk pemakaian bahasa dalam perspektif tertentu yang menjadi perhatian penyair; kedua, berhubungan dengan gaya dalam menyikapi bahasa di dalam sajak. Oleh sebab itu, sekalipun bahasa yang dipakai di dalam puisi sama dengan bahasa sehari-hari, tetapi ada sesuatu yang membedakan antara bahasa sehari-hari dibandingkan dengan bahasa puisi karya seorang penyair, bahkan jika dibandingkan dengan bahasa puisi karya penyair lain.

Oleh sebab puisi merupakan tindak pemakaian bahasa, maka memposisikan puisi sebagai suatu struktur yang memiliki sistem adalah penting. Sistem tersebut, pertama berkenaan dengan sistem bahasa sebelum menjadi medium ungkap puisi, dan kedua sistem bahasa setelah menjadi bahasa ungkap puisi. Sistem bahasa dalam perspektif pertama itu berhubungan dengan arti referensial (meaning) yang disepakati masyarakat pemakai bahasa, dengan kata lain bahasa merupakan tanda tingkat pertama. Sementara itu, sistem bahasa dalam perspektif kedua itu berhubungan dengan makna (significance), yang direkonstruksi oleh penyair dengan mendasarkan diri kepada sistem arti dari masyarakat pemakai bahasa tersebut. Dalam hal ini, bahasa puisi dipersepsikan sebagai tanda tingkat kedua. 
Dengan begitu, bahasa sebelum dijadikan bahasa ungkap di dalam puisi pun sudah dipersepsi sekaligus diposisikan sebagai sistem tanda (tingkat pertama), dan tatkala dipakai sebagai bahasa ungkap puisi, maka tanda tingkat pertama itu ditingkatkan pemaknaannya menjadi "tanda yang ditandakan" (tanda tingkat kedua). Oleh sebab itu, menempatkan puisi sebagai sistem tanda menjadi tidak dapat dihindari, karenanya untuk menafsirkan makna puisi sebagai sistem tanda haruslah dimaknai.

Sementara it u, simbol merupakan salah satu jenis tanda yang bersifat arbitrer dan konvensional, dengan begitu simbol merupakan ekuivalen dari pengertian Fedinand de Saussure tentang tanda (Budiman, 1999:108). Di dalam bahasa puisi, peningkatan makna terhadap bahasa sebagai sistem makna tingkat pertama kepada sistem makna tingkat kedua itu, oleh penyair, dilakukan dengan cara menempatkan kata atau kata-kata menjadi bersifat figuratif. Kata atau kata-kata pada konteks bahasa puisi dipersepsi dan diposisikan sebagai lambang atau simbol. Karenanya, pemaknaan puisi berarti menafsirkan atau memberi interpretasi terhadap lambang atau simbol itu.

Demikian halnya, menafsirkan makna konsep cinta di dalam Sajak-sajak Cinta Gandrung ini dilakukan dengan memposisikan bahasa yang "diindahkan" itu, baik dari aspek estetik maupun etiknya, sebagai sistem komunikasi sastra yang melibatkan simbol-simbol, melibatkan tanda-tanda. Dalam sistem komunikasi sastra, hal demikian melibatkan penyair sebagai pencipta teks, teks, dan pembacanya.

Memang, memahami suatu teks itu tidak menut up kemungkinan perbedaan tafsir, bahkan kesalahpahaman tafsir. Hal itu banyak faktor yang mendasarinya. Pertama, kesalahpahaman tafsir itu disebabkan oleh kenyataan bahwa puisi merupakan tindak pemakaian bahasa, yang sebelum dijadikan medium puisi sudah dipersepsi dan diposisikan sebagai tanda yang memiliki arti oleh pemakai bahasa di dalam suatu masyarakat. Kedua, kesalahpahaman tafsir itu disebabkan oleh kenyataan bahwa puisi merupakan pemakaian bahasa secara tidak langsung. Ketaklangsungan ekspresi puisi itu disebabkan penggunaan metafora yang menjadi bagian vital dari sistem sastra yang digunakan sebagai bahasa ungkap puisi, karenanya puisi menjadi memiliki banyak tafsir (polyinterpretable). Oleh sebab itu, memaknai puisi sebagai teks sastra sangat tergantung kepada interpretasi pembaca sebagai pemberi makna.

Karena berurusan dengan interpretasi terhadap simbol sebagai bagian dari sistem sastra, penulis menggunakan teori interpretasi untuk telaah ini, yakni hermenutika sebagai sistem interpretasi, yang secara metodologi dikembangkan 
oleh Paul Ricoeur. Adapun wacana hermeneutika dalam perspektif tasawuf (ta'wil) dijadikan pijakan bagi langkah filosofisnya, yaitu berpikir dengan menggunakan simbol sebagai titik-tolaknya.

Tentang pendapat Paul Ricoeur bahwa "pemahaman merupakan cara berada atau cara 'menjadi', dan bukan cara mengetahui atau cara memperoleh pengetahuan" ini, Paul Ricoeur hanya ingin menyentakkan kesadaran kita bahwa hermeneutik adalah sebuah metode yang sejajar dengan metode di dalam sains. Ia tidak berkehendak memperlakukan metode hermeneutika ini dengan kaku dan terstruktur sebagaimana terdapat di dalam ilmu ilmiah lainnya. Mengapa demikian? Bagi Paul Ricoeur "Sebab pemahaman adalah salah satu aspek 'proyeksi Dasein' (proyeksi manusia seutuhya) dan keterbukaannya terhadap being." Dengan begitu, "Pertanyaan tentang kebenaran bukan lagi menjadi pertanyaan tentang metode, melainkan pertanyaan tentang pengejawantahan being untuk being, yang eksistensinya terkandung di dalam pemahaman terhadap being”. Hal itu sebab kita memahami manusia dari segala aspek yang ia miliki, manusia seutuhnya, manusia sebagai Dasein: sejarahnya, cara hidupnya, cita-citanya, gaya penampilan, keburukannya, serta segala sesuatu yang membuatnya menjadi "khas". Oleh sebab itu, kita memahami manusia sebagaimana ia "menjadi" (Sumaryono, 1999:111-112; bandingkan, Ricoeur dalam Bleicher, 2003:365-374).

Dalam hal ini, hermeneutika tatkala "memahami" manusia dan hasil kerja budayanya, termasuk di dalamnya kesusastraan, yakni dengan jalan melakukan interpretasi. Namun, apakah setiap orang dapat mencapai pemahaman pada tingkat tertinggi sebagaimana korespondensi satu lawan satu antara penafsir dan sasarannya? "Pemahaman" tersebut, memang terlalu ideal, dan sulit dijangkau oleh ilmu-ilmu alamiah sekalipun. Ada perbedaan antara seorang pakar bidang sains dan seorang hermeneut dalam memahami sesuatu. Seorang pakar bidang sains berhenti pada kasus yang ia terangkan sebagai suatu fakta atau peristiwa, dan ia bergantung kepada diagram ilmiah untuk memberikan penjelasannya. Sementara itu, seorang hermeneut memahami sesuatu tanpa harus ada penjelasan yang terikat kepada diagram ilmiah tertentu sebab ia mempergunakan "metode interpretasi" (Sumaryono, 1999:111-112).

Bagaimana langkah pemahaman terhadap teks itu diimplemantasikan kepada teks sastra? Dalam buku Paul Ricoeur lain, Rule of Mataphor(1977) (via Hadi W.M., 2004:90-92), ia menegaskan bahwa "setiap teks berbeda komponen dan struktur bahasa atau semantiknya, oleh karena itu dalam memahami teks diperlukan proses hermeneutik yang berbeda pula." Apalagi yang dihadapi 
adalah teks sastra, hermeneut harus mampu membedakan antara bahasa puitik yang bersifat simbolik dan metaforikal, dengan bahasa diskursif non-sastra yang tidak simbolik. Perlakuan pemaknaan teks sastra berbeda dengan teks selainnya itu diakibatkan bahasa sastra memiliki kekhasan, yang ciri utamanya dapat dikenali sebagai berikut.

Pertama, bahasa sastra dan uraian falsafah bersifat simbolik, puitik, dan konseptual. Di dalamnya berpadu makna dan kesadaran. Kita tidak dapat memberi makna referensial terhadap karya sastra dan falsafah sebagaimana dilakukan terhadap teks yang menggunakan bahasa penuturan biasa. Bahasa sastra menyampaikan makna secara simbolik melalui citraan-citraan dan metafora yang dicerap oleh indra, sedangkan bahasa bukan sastra berusaha menjauhkan bahasa atau kata-kata dari dunia makna yang luas.

Kedua, dalam bahasa sastra pasangan rasa dan kesadaran menghasilkan objek estetik yang terikat pada dirinya. Penandaan harus dilakukan, dan tanda harus diselami maknanya, tidak dapat dibaca secara sekilas lintas. Tanda dalam bahasa simbolik sastra mesti dipahami sebagai sesuatu yang mempunyai peran konotatif, metaforikal, dan sugestif.

Ketiga, bahasa sastra berpeluang menerbitkan pengalaman fictional dan pada hakikatnya lebih kuat dalam menggambarkan ekspresi kehidupan (via Hadi W.M., 2004:90-92).

Dalam upaya interpretasi teks diperlukan proses hermeneutik yang berbeda itu, menurut Paul Ricoeur, prosedur hermeneutikanya secara garisbesar dapat diringkas sebagai berikut.

Pertama, teks harus dibaca dengan kesungguhan, menggunakan symphatic imagination (imajinasi yang penuh rasa simpati).

Kedua, penta'wil mesti terlibat dalam analisis struktural mengenai maksud penyajian teks, menentukan tanda-tanda (dilal) yang terdapat di dalamnya sebelum dapat menyingkap makna terdalam dan sebelum menentukan rujukan serta konteks dari tanda-tanda signifikan dalam teks. Barulah kemudian penta'wil memberikan beberapa pengandaian atau hipotesis.

Ketiga, penta'wil mesti melihat bahwa segala sesuatu yang berhubungan dengan makna dan gagasan dalam teks itu merupakan pengalaman tentang kenyataan non-bahasa (via Hadi W.M., 2004:90-92).

Akhirnya, apakah interpretasi mempunyai titik akhir? Paul Ricoeur (via Sumaryono, 1999:113) menjawabnya bahwa "Interpretasi selalu bersifat openended sebab jika kita memperoleh titik akhir dari suatu interpretasi, hal ini berarti "pemerkosaan" terhadap interpretasi". 


\section{Puisi Sufi}

Berkenaan dengan istilah sufi dan tasawuf itu sendiri, banyak versi yang meriwayatkannya darimana istilah itu berasal, dan banyak buku yang telah membahasnya, untuk menyebut beberapa saja di antaranya buku Hamka, Abubakar Aceh dengan mengacu pada pendapat Zaki Mubarok dari kitabnya At-tasawwuful Islami fil Adab wal Akhlaq (1937), Harun Nasution. Di samping itu, pengkaji tasawuf dari Barat adalah Annemarie Schimmel, Titus Burckhardt, dan William C. Chittick.

Sementara itu, tasawuf sebagai ilmunya kaum sufi, pengertian yang tumbuh dan dikembangkan kemudian juga banyak sekali, bahkan setiap sufi memiliki makna masing-masing sesuai dengan pengetahuan dan penghayatan kesufiannya. Beberapa contohnya sebagai berikut.

Dalam perspektif ilmu pengetahuan, mengutip pandangan Abu al-Wafa' al-Ghanimi al-Taftazani - guru besar Filsafat Islam dan Tasawuf di Universitas Kairo, dan ketua Himpunan Sufi Mesir - (1997:10), tasawuf dalam Islam melewati berbagai fase dan kondisi. Pada setiap fase dan kondisi yang dilewatinya terkandung berbagai pengertian, yang setiap fasenya hanya mencakup sebagian aspek-aspek saja. Meskipun begitu, ada satu asas tasawuf yang tidak pernah diperselisihkan, yakni tasawuf ialah moralitas yang berdasarkan Islam. Dengan mengutip al-Kattani, al-Tafzani menyimpulkan bahwa "Tasawuf ialah moral. Barangsiapa yang di antaramu semakin bermoral, tent u jiwanya kian bening".

Memang, kita bisa bertolak dari beberapa pandangan di atas, tetapi akan lebih berguna apabila kita mengakui bahwa tasawuf adalah "Pengalaman keagamaan yang autentik", sebagai yang diisyaratkan oleh William C. Chittick (2002:12) setelah banyak mengkaji pemikiran dan implikasinya pada kehidupan sufi terbesar Jalaluddin Rumi dan karyanya. Menurut pernyataan para guru sufi yang dikutip oleh William C. Chittick, mereka berbicara at as nama spirit tradisi Islam yang senantiasa hidup. Di mana pun spirit ini hidup, maka Islam akan senantiasa hidup dengan cita-cita moral dan spiritualnya sendiri. Identifikasi tasawuf dengan spirit Islam telah dikukuhkan dengan sebuah hadis terkenal dari Nabi Muhammad SAW yang dikenal sebagai "hadis Jibril" (konsep tentang Islam, iman, dan ihsan), berkenaan dengan tasawuf terutama sekali berhubungan dengan konsep ihsan (kebajikan) yakni: "Beribadahlah kepada Allah seolah-olah engkau melihat-Nya. Akan tetapi, apabila engkau tidak melihatNya, sesungguhnya Dia melihatmu." Yang mengurai tentang lima Rukun Islam ialah para ahli hukum (fuqaha), dan yang mengurai tentang masalah keimanan 
adalah para teolog (mutakallimun), sedangkan yang menjadikan ihsan sebagai bidang kajian utama dan implikasinya dalam kehidupannya adalah kaum sufi.

Dari pengertian sufi dan tasawuf yang dibahas subbab sebelumnya dapat diidentifikasi bahwa tasawuf berhubungan dengan moralitas Islam. Dengan begitu, spiritualitas tasawuf bersumberkan dari al-Qur'an dan As-Sunnah (Hadis). Sekalipun ada sumber lain, yakni As-Sunnah, dan amalan serta ucapan para sahabat Nabi Muhammad SAW, tetapi amalan dan ucapan para sahabat itu tidak pernah keluar dari ruang-lingkup keduanya, al-Qur'an dan as-Sunnah.

Untuk memetakan sumber tasawuf ini, penulis menyetujui al-Taftazani (1997:33) yang mendukung kajian dari Louis Massignon, seorang orientalis Prancis. Massignon menyimpulkan bahwa sumber tasawuf ada empat: pertama dan utamanya adalah al-Qur'an; kedua, ilmu-ilmu Islam seperti Hadis, Fiqh, Nahwu, dan lainnya; ketiga, terminologi ahli ilmu kalam angkatan pertama; keempat, bahasa ilmiah yang terbentuk di Timur sampai enam abad permulaan Masehi adalah dari bahasa lain seperti Yunani dan Persia yang menjadi bahasa ilmu pengetahuan.

Sehubungan tasawuf bersumber dari al-Qur'an dan as-Sunnah ini, kita perlu kembali sedikit mengupas konsep dasar spirit Islam yang dipetakan melalui "hadis Jibril" tentang Islam, iman, dan ihsan. Nabi Muhammad SAW mendifinisikan Islam sebagai "Bersaksi bahwa tiada tuhan selain Allah dan bahwa Muhammad adalah ut usan Allah, mendirikan shalat, membayar zakat, berpuasa Ramadhan, dan menunaikan ibadah haji." Nabi SAW juga menyatakan bahwa iman adalah "Percaya kepada Allah, para malaikat, kitab-kitab, para rasul, hari kiamat, dan takdir Allah (yang baik maupun yang buruk)." Nabi SAW juga menegaskan bahwa ihsan adalah "Beribadahlah kepada Allah seolaholah engkau melihat-Nya. Akan tetapi, apabila engkau tidak melihat-Nya, sesungguhnya Dia melihatmu" (Sumber hadis Jibril ini diambil dari Murata dan Chittick, The Vision of Islam, Terj. Suharsono, 2005: xxxi-xxxiii). Kedudukan ihsan inilah yang seringkali dilupakan oleh para ahli hukum Islam maupun para teolog Islam, padahal ihsan merupakan jiwa dari agama, yang kedudukannya sama pentingnya dengan dua kategori lainnya, Islam dan iman.

Tiga hal tersebut merupakan tiga domain dasar religiositas Islam, yang implikasinya sebagaimana hadis Nabi SAW: "Iman adalah membenarkan dengan hati, mengikrarkan dengan lisan, dan mengamalkan dengan anggota badan.” Domain aktivitas yang benar menjadi kajian para ahli hukum Islam, domain pemikiran yang benar menjadi kajian para teolog, sedangkan domain penglihatan yang benar menjadi kajian khusus kaum sufi. Dalam hal ini, 
seseorang tidak bisa melihat "segala sesuatu" sebagaimana adanya dengan mata dan pikiran, melainkan dengan hati, sebagaimana hadis Nabi SAW: "Ya Allah, tunjukkanlah kepada kami segala sesuatu sebagaimana adanya."

Pandangan tasawuf tentang realitas tersebut juga bersumber dari al-Qur'an dan hadis, tetapi pandangan ini telah diadaptasi secara turun-menurun oleh para guru sufi kepada muridnya. Pandangan demikian mampu membuat orang memahami keadaan mereka dalam hubungannya dengan Allah. "Tidak ada tuhan kecuali Allah" (laailaha illallaah), memberi batasan yang tegas antara Allah dan segala sesuatu selain-Nya yakni alam semesta. Secara keseluruhan syahadat mengandung arti "tidak ada hakikat kecuali Allah", dan bahwa semua yang kita sebut sebagai realitas dalam pengalaman kita sesungguhnya hanya bersifat sekunder dan tidak berdiri sendiri. Senada dengan salah satu ayat alQur'an yang terkenal berkenaan dengan pemahaman terhadap realitas bahwa "Segala sesuatu binasa kecuali wajah-Nya" (Q.S., al-Qashas/28:8). Pembedaan awal antara Allah dan alam semesta ini melahirkan pembedaan kedua, yakni pembedaan antara wahyu dan pengetahuan manusia, yang hal ini didiskripsikan dalam kalimat: "Muhammad adalah utusan Allah" (Muhammadarrasulullaah). Orang harus membedakan antara wahyu dan pengetahuan manusia, antara alQur'an dan usaha manusia untuk memahaminya, antara tanda dan hijab, antara Timur dan Barat. Setelah melakukan pembedaan ini, mereka harus mengamalkannya. Untuk pengamalan ini, dengan mengutip William C. Chittick (2002:39) bahwa "Ajaran-ajaran dan institusi-institusi agama memberikan sarana praktis untuk memilih wajah Timur daripada wajah Barat."

Dengan begitu dalam pandangan tasawuf, syahadat menjadi ungkapan konkret tentang realitas absolut Allah. Namun demikian, senada diungkapkan William C. Chittick (2002:39), bimbingan syariat tetap memiliki fungsi, tetapi kaum sufi menerimanya bukan "karena mereka merasa harus demikian", melainkan karena kesadaran bahwa bimbingan ini memainkan peran mendasar dalam memungkinkan manusia berbuat sesuai dengan kebenaran wahyu dan menghindari kesalahan dan dosa.

\section{Puisi Sufi A. Mustofa Bisri}

Membaca sajak-sajak cinta Gandrung karya A. Mustofa Bisri ini, pembaca akan lekas menemui ciri khasnya. Ciri khas perpuisian A. Mustofa Bisri dalam buku Gandrung ini dalam mengekspresikan bahasanya "tidak memperindah kata-kata", seperti halnya dia ungkapkan dalam sajak "Aku Tak Akan Memperindah Kata-kata". Namun, "kesahajaan bahasa sajak" itu tidak berarti 
kemudian sajaknya jadi gamblang pemaknaannya sebab bagaimanapun puisinya begitu kaya simbol yang memiliki keterkaitan dengan alam pikir religius, bahkan mistisisme Islam (tasawuf). Oleh karenanya, untuk sampai kepada makna batin sajak, pembaca dituntut memiliki wawasan tentang alam pikir yang melatari penciptaan sajaknya. Alam pikir tersebut merupakan perpaduan pengalaman mistik dan pengalaman estetik, yang digambarkan melalui tamsil (perbandingan, perumpamaan) metafisik.

Dalam teori puisi, penggunaan bahasa sajak yang demikian seringkali disebut bersifat "kesederhanaan yang menipu" (deceptive simplicity). Hal itu diasumsikan akibat dari sifat dasar dari puisi, yakni mengungkapkan sesuatu secara tidak langsung (ketaklangsungan ekspresi) melalui penggantian arti (displacing of meaning), penyimpangan arti (distorting of meaning) dan penciptaan arti (creating of meaning) (Riffaterre, 1978:2).

Oleh sebab itu, ungkapan bahasa dalam sajak yang tampaknya sederhana menjadi tidak sederhana apabila pembaca memahami penggantian arti, penyimpangan, dan penciptaan arti dalam sajak itu. Meskipun begitu, alasan ini bersifat estetisme, yang hanya mempertimbangkan aspek bahasa sajak sebagai penggunaan bahasa yang menyimpang dari arti umum (meaning).

Akan tetapi, dangkalnya pemaknaan terhadap suatu sajak tidak saja diakibatkan oleh alasan yang bersifat estetisme. Dalam konteks perpuisian yang mengungkapkan pengalaman religius (religious experience), dangkalnya pemaknaan terhadap sajak lebih diakibatkan si Pemakna tidak dapat mencari rujukan makna terhadap simbol-simbol yang dia maknakan sehingga terjadilah pendangkalan pemaknaan, bahkan menyimpangnya pemaknaan terhadap suatu sajak yang sebenarnya mengungkapkan pengalaman religius itu. Demikian misalnya pada sajak A. Mustofa Bisri dari buku puisi Gandrung (2000:21) ini.

\section{Aku Tak Akan Memperindah Kata-kata}

Aku tak akan memperindah kata-kata

Karena aku hanya ingin menyatakan

Cinta dan kebenaran

Adakah yang lebih indah dari

Cinta dan kebenaran

Maka memerlukan kata-kata indah? 
Kata "Cinta dan kebenaran" yang dimunculkan dan menjadi pasal dari sajak tersebut, jelas dalam "arti" (meaning), tetapi debatable dalam "makna" (significance). Hal itu sebab memunculkan pertanyaan, "cinta" dalam makna yang mana? dan, "kebenaran" dalam makna yang mana? serta, apa hubungan makna antara "cinta" dan "kebenaran" dalam konteks puisi A. Mustofa Bisri? Di samping itu, mengapa untuk "...menyatakan/ Cinta dan kebenaran//" A. Mustofa Bisri “...tak akan memperindah kata-kata/...”?

Pertanyaan-pertanyaan itu sudah dijawab sendiri oleh A. Mustofa Bisri sebab demi "Sesuatu yang Indah". "Sesuatu yang Indah" itu menurutnya tidak lagi "...memerlukan kata-kata indah" sebab "Cinta dan kebenaran" itu sendiri adalah esensi dari keindahan. Kemudian, kepada siapakah trinitas antara "Cinta dan kebenaran" serta "keindahan" itu dialamatkan? Tentu, dialamatkan kepada Allah, bahkan A. Mustofa Bisri memohon "cinta dan kasih sayang" itu kepadaNya: "Ya Allah, ya Tuhanku yang Maha Pengasih/ Ya Allah ya Tuhanku yang Maha Penyayang/Kiranya tak ada permintaan yang lebih besar/ dariku—/ dan tak ada anugerah sebesar apa pun dariMu/ dapat mengurangi kebesaranMu/: ya Tuhan, aku memohon cinta dan kasih sayang!//" (Sajak "Doa Pecinta 2", 2000:68).

Alam pikir sajak A. Mustofa Bisri itu diilhami oleh ungkapan terkenal dari Nabi Muhammad SAW bahwa "Sesungguhnya Allah itu Yang Maha Indah dan mencintai keindahan (InnaLlaha jamil wa yuhibbul jamal)," (hadis dari Abdullah Mas'ud, dikutip dari asy-Syarif, 2003:338; Terj. Hanafi \& Fattah).

Oleh sebab itu, trinitas kata "Cinta dan kebenaran" serta "keindahan" dalam konteks puisi A. Mustofa Bisri harus dipersepsi dan diposisikan sebagai simbol, yang memaknakannya dengan mempertimbangkan teks lain dalam perpuisiannya, dengan mempertimbangkan konteksnya dan mempertimbangkan kontekstualisasinya. Ketiga aspek tersebut, teks, konteks, dan kontekstualisasi, merupakan hakikat dari suatu interpretasi, hermeneutika interpretasi.

Dalam tradisi puisi profetik karya dunia, "tidak memperindah kata-kata" tersebut menjadikan "kesahajaan bahasa sajak", yang hal itu justru menjadi sebuah pilihan. Mengapa "kesahajaan bahasa sajak" itu dipertahankan? Hal ini sebagaimana pernah diungkapkan dengan indah oleh Annemarie Schimmel dalam bukunya Menyingkap Yang-Tersembunyi (Terj. Saini K.M., Cet. I, 2005:40):

"Sesungguhnya, ketunggalan-nada yang lugas dan lurus dalam pesan profetis memang diperlukan agar isi wahyu yang diterima Nabi dapat dipertahankan kemurniannya, sehingga tidak ada perubahan padanya. Sebagai akibatnya, 
seorang penyair Muslim yang menulis sajak dalam tradisi "profetis" cenderung menggunakan bentuk yang sederhana untuk menekankan pesannya ke dalam pembacanya."

Dengan demikian, penyair dalam tradisi "profetis" menulis puisinya dengan kesadaran penuh bahwa ia mengurai pengalaman religiositasnya yang eksoterik. Oleh sebab itu, formula sajak dan pengalaman religiositas yang dikabarkannya pun bukanlah "Menyingkap Yang-Tersembunyi", melainkan dunia dan "Puisi-puisi Terang" seperti diistilahkan sendiri oleh A. Mustofa Bisri dalam salah satu subbagian buku puisinya Pahlawan dan Tikus (Cet. II, 2005:47).

Akan tetapi, baik penyair profetik maupun penyair mistik pun memiliki kesadaran bahwa mereka berhadapan dengan mukjizat yang berupa bahasa alQur'an yang tidak mungkin ditandingi. Oleh sebab itu, para penyair profetik ataupun para mistikus penyair secara terus-menerus merenungkan al-Qur'an, dengan begitu

"suatu ingatan yang ter-Qur'an-kan (qoranisation de la memoire) dapat dicapai, yang dengan itu para mistikus kemudian memandang segala sesuatu dari sudut-pandang wahyu. Mereka pun setiap saat mengambil inspirasi alQur'an, dan menerapkan lambang-lambangnya ke pengalaman mereka sendiri" (Schimmel, 2005:43).

"Hidup di dalam dan melalui al-Qur'an seperti itu membantu pembentukan pengalaman para mistikus dan bahasa mereka" (Schimmel, 2005:43). Dalam konteks ini, bagaimana dengan perpuisian A. Mustofa Bisri?

Tatkala memasuki dunia keprofetikan, tentu saja sajak A. Mustofa Bisri akan berbeda nuansa, ekspresi kebahasaan, simbolitas, bahkan persepsi dan pemosisian aku-lirik dalam sajak, dibandingkan dengan sajak sufistis (dan sufisme)-nya. Yang paling mudah membedakan antara keduanya ialah tatkala mempersepsi dan memposisikan "aku" di dalam sajak. Dalam konteks keprofetikan, Tuhan dipersepsi dan diposisikan sebagai Yang Maha Transenden ("Jauh di Atas Sana"). Sementara itu, manusia berada di bawah langit, bersimpuh di hamparan bumi dalam kedinginan hidupnya yang membutuhkan uluran kehangatan pelukan Tuhan. Namun, ada tabir di antara keduanya sebab manusia hanyalah makhluk, sedangkan Tuhan adalah Sang Maha Pencipta (alKhaliq) atas semua makhluk. Bagaimana mungkin keduanya bisa saling berdekatan? Cukuplah kiranya manusia dalam persepsi dan posisi ini memujaNya sebagai Yang Maha Tinggi (al-Aliyy), Yang Maha Kuasa (al-Qadir), Yang Maha Penyiksa manusia yang lalai (al-Muntaqim), Yang Maha Mematikan (al- 
Mumit), dan Nama-nama dan Sifat-sifat-Nya yang maskulin semacam itu. Sudut-pandang keprofetikan ini memang dominan dalam perpuisian A. Mustofa Bisri, terutama sekali dalam buku puisi 1. Ohoi (1991), 2. Tadarus (cet.1, 1993), 3. Pahlawan dan Tikus (1995), 4. Rubayat Angin dan rumput (1995), 5. Wekwekwek: Sajak-sajak Bumilangit (1996), dan dalam buku puisi yang terbit urutan ke-7, Negeri Daging (2002). Sementara itu, buku puisi yang terbit pada urutan ke-6 Sajak-sajak Cinta Gandrung (2000), diwarnai oleh sudut-pandang mistisisme Islam.

Tipikal mencitrakan keprofetikan A. Mustofa Bisri itu di antaranya dalam sajak "Ketika Tuhan" dari buku puisi Pahlawan dan Tikus (2005:33). Sajak berikut ini mengkontekstualisasikan teks al-Qur'an sebagai salah satu ciri dari tradisi perpuisian profetik, ketika Tuhan dan para malaikat-Nya berdialog tentang maksud penciptaan manusia (al-Baqarah, 2:30):

"Perhatikanlah sewaktu Tuhanmu berfirman kepada para malaikat,

'Aku akan menciptakan khalifah di bumi.'

Mereka bertanya keheranan, 'Mengapa

Engkau akan menciptakan makhluk yang

akan selalu menimbulkan kerusakan

dan pertumpahan darah di bumi,

sementara kami senantiasa bertasbih memuji

dan mensucikan Engkau? “

Allah berfirman, 'Aku Mahatahu akan hal-hal yang tidak kamu ketahui."

Ketika Tuhan

Ketika Tuhan menyampaikan

MaksudNya menciptakan manusia

Sebagai khalifahNya di dunia

Para malaikat pun berkata

Tuhan, mengapa Paduka 


\author{
Hendak mencipta \\ Makhluk perusak di sana \\ Penumpah darah semena-mena \\ Sedangkan kita \\ Terus bertasbih dan memuja \\ Paduka? \\ Tuhan pun bersabda \\ Aku tahu apa \\ Yang kalian buta \\ Terhadapnya
}

Ketika sang khalifah benar-benar semena-mena

Merusak dan menumpahkan darah di mana-mana

Di dunia

Apakah kita akan membenarkan para malaikat dan berkata

KepadaNya seperti mereka lalu siapakah kita

Yang tahu kehendak Sang Pencipta?

1414

Namun demikian, pada tingkat tertent u seorang penyair profetik yang memasuki kehidupan mistik, seperti A. Mustofa Bisri, akan tidak "sekadar" mengungkapkan bahasa profetis yang bersetia secara normatif kepada kebakuan simbol yang diadopsi dari simbol dalam al-Qur'an. Hal itu sebab pada dasarnya mistikus adalah seorang "petualang mandiri” yang tujuannya adalah keakraban dengan Tuhan (uns). Di dalam keakraban cinta dengan Tuhannya, di tengah malam seorang mistikus menjelma menjadi seorang kekasih yang memuja Yang Maha Kekasihnya. Oleh sebab itu, dia tidak lagi menyeru dengan "Wahai Tuhanku ....." sebagaimana hal itu dilakukan oleh seorang ulama fikih di tengah umat di siang hari, melainkan dengan bisikan-bisikan seorang pencinta dalam kemesraan yang dalam, "Wahai Kekasihku, wahai Cintaku....." Demikian halnya A. Mustofa Bisri dalam seluruh sajaknya di dalam buku puisi Gandrung, dia menjelma menjadi seorang mistikus cinta yang sejati, seperti "Sajak Cinta" berikut ini (2000:12-13). 


\title{
Sajak Cinta
}

\author{
cintaku kepadamu belum pernah ada contohnya \\ cinta romeo kepada juliet si majnun qais kepada laila \\ belum apa-apa \\ temu pisah kita lebih bermakna \\ dibanding temu-pisah Yusuf dan Zulaikha \\ rindu-dendam kita melebihi rindu-dendam Adam \\ dan Hawa
}

aku adalah ombak samuderamu yang lari-datang bagimu hujan yang berkilat dan berguruh mendungmu

aku adalah wangi bungamu luka berdarah-darah durimu semilir sampai badai anginmu aku adalah kicau burungmu kabut puncak gunungmu tuah tenungmu aku adalah titik-titik hurufmu huruf-huruf katamu kata-kata maknamu

aku adalah sinar silau panasmu dan bayang-bayang hangat mentarimu

bumi pasrah langitmu

aku adalah jasad ruhmu

fayakun kunmu

aku adalah a-k-u $\mathrm{k}-\mathrm{a}-\mathrm{u}$ $\mathrm{mu}$

Rembang, 30.9.1995 
Ekspresi "petualang mandiri" demi keakraban dengan Tuhan (uns) ini pun berpengaruh kepada ekspresi bahasa sajaknya yang juga mandiri, tak terkecuali sajak di atas, dan karenanya khas, bukan tiruan dari ekspresi bahasa sajak penyair lain sehingga orisinal. Hal itu sebab pada dasarnya setiap perpuisian yang estetik dan orisinal merupakan hasil dari "pengalaman mistik" yang juga estetik dan orisinal, yang mandiri sebab bersifat personal: "cintaku kepadamu belum pernah ada contohnya/ .../ temu-pisah kita lebih bermakna/ dibanding temu-pisah Yusuf dan Zulaikha/...," ungkap A. Mustofa Bisri sedemikian personal, antara Tuhan dan dirinya. Personalitas pengalaman mistik ini yang menunt un kepada personalitasnya ekspresi bahasa sajak seseorang mistikus penyair sehingga ada keunikan yang tidak dimiliki oleh penyair lain.

Boleh jadi, setiap pendakian jalan (thariqah) yang dilalui seorang mistikus (sufi) pada hakikatnya menuju kepada satu puncak yang sama, yaitu Allah. Namun demikian, setiap pengalaman mistik itu bentuk-bentuknya tidaklah sama sehingga prioritas jalan yang ditempuh pun berbeda-beda, karenanya tingkatan-tingkatan (maqamat) yang ditempuh juga memiliki penekanan yang berbeda-beda sehingga menghasilkan pengungkapan mistik yang estetik yang berbeda-beda pula. Oleh sebab itu, selalu saja ada yang baru dan segar dari setiap pengungkapan pengalaman mistik di dalam puisi setiap mistikus penyair.

Pengalaman mistik-estetik yang mandiri tersebut menghasilkan bahasa sajak mistik-estetik yang mandiri pula, hal itu dapat dimaknakan sebagai "kemerdekaan" berekspresi melalui bahasa "sajak-bebas" agar kebebasan penyair untuk menyimpang dari konvensi kebahasaan dapat dilakukannya (licensia poetica). Hal tersebut juga dilakukan oleh A. Mustofa Bisri pada seluruh sajaknya di dalam buku puisi Gandrung ini bahwa perpuisiannya secara wadag kebahasaan terlihat tidak memiliki keteraturan rima. Hal demikian justru ada maknanya apabila kita mengikuti temuan dari hasil penelitian Hagiwara Sakutaro tentang adanya ritme metafisik (metaphisical rythm) yang terdapat pada setiap puisi yang bagus, terutama sekali pada puisi transendental. Alasan Hagiwara Sakutaro ini dikutip secara panjang oleh Abdul Hadi W.M. bahwa:

Puisi dapat dimaknakan puisi bukan hanya karena keteraturan rima, jumlah suku kata pada setiap larik atau kerat, pendek kata bukan karena susunan formalnya, melainkan karena "semangat puitik" (shisheisin) yang berada di baliknya.

Dalam pengertian yang sempit, menurut Hagiwara Sakutaro, ritme merupakan alunan irama atau gerakan temporal dari bunyi yang menghasilkan efek tertentu terhadap perasaan si pendengar. Dalam puisi, ritme seperti ini ditandai dengan pengaliran unsur-unsur fonetik bahasa seperti aksen, tekanan 
suara, nada dan lain-lain, yang disebut sebagai "ritme lahir". Tetapi, di samping itu terdapat "ritme dalam" yang memberi pengaruh khusus terhadap perasaan, yakni ritme emotif (emotive rythm), dan dapat membawa pembaca ke alam transendental, yakni ritme metafisik (metaphisical rythm). Setiap sesuatu yang indah, terutama puisi transendental, memiliki ritme metafisik. Ritme metafisik terbentuk oleh makna, keindahan tamsil yang digunakan, penempatan katakata sesuai dengan struktur pikiran dan perasaan yang hendak diekspresikan, walaupun bentuk lahirnya kelihatan tidak teratur (2001:207-208; dari Makoto Ueda, Modern Japanese Poets and the Nature of Literature, 1983:167-169).

"Setiap sesuatu yang indah, terutama puisi transendental, memiliki ritme metafisik." Ritme metafisik ini di dalam puisi A. Mustofa Bisri pertama kali tampak dimunculkan melalui "ritme lahir" berupa "ketidakteraturan tipografi" sehingga di saat membaca satu sajak akan memungkinkan sajak itu dibaca dengan beragam aksen, tekanan nada, dan penjedaan pada saat melakukan pemutusan frase atau kalimat secara berbeda-beda. Di samping itu, "ketidakteraturan tipografi" ini menjadi kesengajaan untuk peloncatan baris (enjambement) sehingga menimbulkan beragam interpretasi makna (poly interpretable) sekalipun hanya bertumpu kepada satu sajak. Sebagaimana "ketidakteraturan tipografi" pada sajak "Seporsi Cinta" berikut ini (2000:33).

Seporsi Cinta

(Diilhami oleh kekasih yang lapar)

Seporsi cinta

Tak habis dimakan

Berdua, sayang

Seporsi cinta

Bila tak habis dimakan

Dibuang sayang

1999

Baris sajak di atas bisa dibaca dengan penjedaan (ditandai dengan garis miring ), yang pertama: "Seporsi cinta/ Tak habis dimakan berdua/ sayang". Kata "sayang" dengan cara pembacaan demikian dapat dimaknakan sebagai, "jangan disia-siakan". Pembacaan dengan penjedaan yang kedua: "Seporsi cinta tak habis dimakan berdua, sayang". Pembacaan dengan setarikan nafas 
ini menjadikan kata "sayang" lebih pasti maknanya, yaitu sebagai sapaan kepada "sang Kekasih".

Tipografi sajak dalam buku puisi Gandrung yang dominan justru disusun secara tidak konvensional sebagaimana sajak "Seporsi Cinta" tersebut, yaitu tidak rata tepi kiri dan tidak rata tepi kanan, melainkan simetris di tengah (center). Akan tetapi, simetris di tengah ini dapat dimaknakan sebagai penampakan tipografi yang seimbang (balance), dan karenanya menimbulkan makna harmoni. Justru karena itu, penulisan puisi menjadi tampak indah dipandang oleh pembaca. Prosentase sajak yang demikian, begitu dominan, ada 38 judul sajak. Hanya ada 1 judul sajak "Cinta Hingga" yang bertipografi rata kanan-kiri (justify), dan selebihnya 5 judul sajak yang bertipografi rata kiri (align lift). Tidak ada satu judul sajak pun yang bertipografi rata kanan (align right) sebagaimana hal ini dijadikan trade merk oleh Binhad Nurrohmat di dalam perpuisiannya, Kuda Ranjang (2004).

Di samping itu, tipografi simetris perpuisian A. Mustofa Bisri ini dapat diposisikan dan dipersepsi sebagai simbol dari upaya aku-lirik manusia untuk melakukan keseimbangan, berdiri di tengah, tidak ekstrem kanan dan tidak ekstrem kiri; memaknai keseimbangan antara yang tersurat (arti) dan yang tersirat (makna), yang wadag dan yang spiritual. Karena keseimbangan ini, maka setiap perilaku aku-lirik manusia tidak dimaksudkan sebagai perbuatan yang sia-sia, seperti dalam menyikapi "Seporsi cinta" yang "Tak habis dimakan/ Berdua...//". Oleh sebab itu, jika “//Seporsi cinta/ Bila tak habis dimakan/", maka janganlah "/Dibuang..." sebab hal itu tentu saja akan "...sayang”, akan sia-sia. Padahal, Allah tidak menyukai hal yang sia-sia (mubadzir), "innal mubadzdziriina kaanuu ikhwaanasy syayaatiina” (Sungguh para pemboros betul-betul saudara setan) (al-Qur'an, 17:27).

"Ketidakteraturan tipografi" ini digunakan secara berulang-ulang dalam sajak A. Mustofa Bisri lainnya di dalam buku puisi Gandrung ini sehingga memunculkan ketaraturan makna bagi pembaca. Walaupun bentuk tipografi (bagian dari ritme lahirnya) kelihatan tidak teratur, tetapi karena digunakan secara berulang-ulang, justru memunculkan ritme metafisik yang terbentuk oleh makna simbolitas tipografi tersebut, yakni makna keseimbangan antara yang tersurat dan yang tersirat, yang wadag dan yang spiritual.

Mengapa ritme metafisik menjadi penting tatkala membicarakan nilai kesastraan maupun keagungan pemikiran suatu karya sastra? Berbicara pentingnya ritme matafisik ini pada hakikatnya kita membicarakan tentang keindahan pengalaman mistik maupun pengalaman estetik yang dituliskan di 
dalam karya sastra, khususnya puisi. Hal tersebut secara panjang Abdul Hadi W.M. mengurai pemikiran al-Jili sebagai berikut (2001:76-77).

Al-Jili membagi keindahan sebuah puisi menjadi dua, yaitu keindahan luar (husn) dan keindahan dalam (jamal). Terdapat perbedaan besar antara kedua keindahan ini, walaupun keduanya saling memerlukan. Keindahan luar atau bentuk memang mempunyai daya pukau yang kuat, yang disebut sihir oleh al-Jili. Walaupun memukau, keindahan luar terbatas dan bersifat khusus (particular). Keindahan batin yang di dalam (jamal) kebalikannya adalah tidak terbatas dan universal. Kekuatan jamal terletak pada kandungan hikmahnya, yaitu pengetahuan tentang hakikat kehidupan. Dalam puisi hikmah berfungsi memperkaya batin pembaca (Braginsky, 1992). Karena sifatnya yang tak terbatas dan universal, serta dapat memperkaya batin itulah para penulis sufi lebih mengutamakan jamal dibandingkan dengan husn, tanpa mengecilkan peranan husn. Dalam puisi keindahan batin melahirkan makna. Maknalah yang merupakan struktur batin puisi. Sedang keindahan luar melahirkan shurah, yaitu bentuk yang ada di luarnya. Shurah adalah wakil makna di alam penampakan dan kehadirannya sepenuhnya ditentukan oleh makna. Shurah merupakan struktur fisik sebuah puisi.

Selanjutnya, tentang "ritme metafisik terbentuk oleh makna, ..." itu juga diungkapkan oleh al-Jurjani, sebagai berikut.

“...karena yang diekspresikan seorang penyair di dalam puisinya ialah struktur pikiran dan perasaan serta struktur realitas yang kompleks, maka makna yang diturunkan oleh sebuah puisi ialah makna dari makna-makna (ma'na alma'na), yang membentang dari makna luar yang sempit, sampai makna dalam yang luas. Dalam membentuk lapisan-lapisan makna itu peranan tamsil atau citra simbolik sangat prinsip dan penting” (via Hadi W.M., 2001:209).

Tamsil (perbandingan, perumpamaan) metafisik tersebut di dalam puisi A. Mustofa Bisri menimbulkan asosiasi metafisik. Sementara itu, bukan kebetulan dalam buku puisi Gandrung karya A. Mustofa Bisri ini ditemukan judul-judul sajak dengan memakai bahasa Arab, yang dari judulnya sudah menimbulkan asosiasi metafisik dan menjadi kata kunci memasuki dunia tasawuf: "Al'isyq" (2000:15, "Keasyikan" - pen; menurut Jalaluddin Rumi bahwa 'isyq adalah cinta yang tidak terbilang banyaknya [Hadi W.M., 2001:36]), "Hanien" (2000:38; "Yang Dirindukan" - pen.), "Ilhaah 1" dan "Ilhaah 2"(2000:53-54; "Makna" - pen.), "Wakhsyah"(2000:60; "Gelisah" - pen.), "Syauq"(2000:61; "Kerinduan" - pen), "Insijam" (2000:62; "Gandrung” atau "Kepayang" - pen.), "Liqaa" (2000:66; "Pertemuan" - pen).

Jika direnungi penataan urutan sajak-sajak tersebut, juga menimbulkan asosiasi metafisik, yakni mencerminkan tingkatan ke tingkatan (maqamat) 
perjalanan spiritual seorang salik ("salikun", "salikin"= penempuh jalan keruhanian, [Hadi W.M., 2001:432]). Perjalanan keruhanian tersebut adalah "Al'isyq" ("cinta yang tidak terbilang banyaknya") - "Hanien" ("Yang Dirindukan") - "Ilhaah" ("Makna") - "Wakhsyah" ("Gelisah") - "Syauq" ("Kerinduan"), "Insijam"( "Gandrung”) - "Liqaa" ("Pertemuan"). Urutan ini merupakan jalan tarekat (thariqah) menuju kepada Allah: dimulai dari "cinta yang tidak terbilang banyaknya" kepada Sang "Kekasih"/ "Yang Dirindukan", yaitu Allah. Demi mencapai "Makna" rahasia ketuhanan itu sehingga sang Salik mengalami ke-"Gelisah"-an, mengalami "Kerinduan" yang luar biasa, sampai-sampai mengalami "Gandrung". Akhir perjalanan keruhanian ini sampailah kepada "Pertemuan" dengan Allah.

Bandingkan, misalnya, tingkatan keruhanian yang disebutkan oleh Annemarie Schimmel (1981:37-38) dan Abu al-Wafa al-Taftazani (1983:85) mencakup: taubat, sabar, raja' (harap), khauf (takut), faqir, zuhud, tauhid (selarasnya kehendak seorang hamba dengan kehendak Ilahi), tawakkul (ketergant ungan penuh kepada Tuhan), dan mahabbah (cinta) yang termasuk di dalamnya syauq (rindu), uns (kekariban) dan ridla (rela).

Judul-judul sajak tersebut dalam perpuisian A. Mustofa Bisri berposisi sebagai citra simbolik, yang menimbulkan lapisan makna, dari makna luar yang memberi gambaran realitas empiris terbatas, sampai kepada makna dalam yang mengandung "hikmah" (kebijaksanaan). Oleh sebab itu, dalam hal ini, tamsil (perbandingan, perumpamaan) atau citra simbolik menjadi penting di dalam perpuisian A. Mustofa Bisri sekalipun sajaknya disampaikan dengan "kesahajaan bahasa sajak". Memang, sajak-sajak A. Mustofa Bisri adalah "sajak yang tak memperindah kata-kata".

Tamsil (perbandingan, perumpamaan) atau citra simbolik tersebut di dalam perpuisian A. Mustofa Bisri sebagian meneruskan tradisi sajak sufi-penyair sebelumnya (yang akan dibicarakan pada subbab selanjutnya), dan sebagian lainnya merupakan temuan khas A. Mustofa Bisri. Demikian contohnya dalam "Sajak Cinta" (2000:12-13) yang mengawali buku puisi Gandrung, di awal subbab sajak ini telah dikutip lengkap.

aku adalah jasad ruhmu

fayakun kunmu

aku adalah a-k-u

$\mathrm{k}-\mathrm{a}-\mathrm{u}$

$\mathrm{mu}$

190

Vol. 13, No. 1, Januari - Juni 2015 
Dua bait terakhir sajak tersebut merupakan citra simbolik khas A. Mustofa Bisri, yang menimbulkan asosiasi metafisik dan bersumber dari ungkapan alQur'an surah Yasin ayat 82. Dari sajak pertama buku puisi ini pun A. Mustofa Bisri telah mempersiapkan pemakaian tamsil metafisik seperti”...//aku adalah jasad ruhmu/ fayakun kunmu//" sebagai wujud kerinduan (syauq) sekaligus kedekatan (uns) kepada Sang Kekasih. Ungkapan tersebut menggambarkan tawakkul (ketergantungan penuh) kepada Sang Kekasih yang teramat dicintainya sehingga "aku" menjadi tidak ada sebab yang ada hanyalah "k-a$\mathrm{u} / \mathrm{mu}$ " (penyatuan mistik = fana).

Sementara itu, memaknai bentuk lahir (shurah) sajak tersebut secara mendalam akan sampai kepada makna batin sajak. Pemaknaan itu pada konteks perpuisian A. Mustofa Bisri, seringkali pembaca dihadapkan kepada penggunaan bahasa sajak dalam "kesederhanaan yang menipu" (deceptive simplicity). Memang, perpuisian A. Mustofa Bisri adalah "sajak yang tak memperindah kata-kata”, sekalipun begitu sajak-sajak A. Mustofa Bisri tetaplah sajak yang indah.

Membaca perpuisian sufi-penyair tampaklah bahwa mereka tidak sekadar "mengindahkan" bahasa di dalam sajak. Sufi-penyair dalam menulis sajak agar sampai kepada dunia makna, tidak memulai perjalanannya dari bahasa atau "menyusun dunia kata", melainkan berangkat dari makna itu sendiri yang tersusun dari pengalaman demi pengalaman mistik yang estetik yang dialaminya. Bahasa sajak diposisikan "hanya" sebagai medium dari keindahan pengalaman mistik yang mereka alami. Karena pengalaman mistik itu sekaligus memiliki kualitas pengalaman estetik, maka hal ini yang menunt un bahasa ungkap mereka menjadi bahasa sajak yang estetik pula.

Bahasa sajak yang estetik itu merupakan cermin keindahan hakiki pengalaman mistik sufi-penyair yang tergambar di dalamnya. Pengalaman mistik ini bagi sufi-penyair menjadi bagian hidup kesehariannya, menjadi mediasi bagi percintaannya dengan Tuhan. Oleh sebab itu, banyak pengakuan sufi-penyair bahwa mereka tidak pernah memaksudkan dirinya sebagai penyair tatkala menulis sajak. Mereka menulis puisi sebab puisi bagian dari komunikasi seorang sufi kepada Tuhan. Dengan begitu, puisi menjadi menggambarkan kemesraan dan ketergantungan penuh kepada Kekasih, dalam mahabbah (cinta) yang diwarnai syauq (rindu), uns (kekariban), dan ridla (rela).

Perpuisian A. Mustofa Bisri termasuk puisi yang berangkat dari makna itu sendiri, yang tersusun dari pengalaman mistik yang estetik yang dialaminya. Oleh karenanya, perpuisiannya tidak menggant ungkan diri kepada "meng- 
indahkan" bahasa ataupun "permainan bahasa". Singkatnya, kualitas estetik "puisi"-nya terletak pada pengalaman mistik yang estetik, yang dicitrakan di dalam sajaknya. Oleh karenanya, seandainya sajak semacam ini diterjemahkan ke dalam bahasa lain pun, maka tidak akan "pecah" kualitas estetik "puisi"-nya. Hal demikian berlaku bagi puisi karya agung seperti karya Rabī'ah alAdawiyah, Abu Sa'id, Dzun Nun, Sana'i, Anshari, al-Hallaj, Ibn 'Arabì, Ibnu Faried, Fariduddin Atṭāar, Rumi, Hafiz, Jami’, bahkan sampai ke puisi Kahlil Gibran. Untuk di Nusantara, hal demikian berlaku bagi puisi karya agung Hamzah Fansuri, Syamsuddin as-Sumatrani, Nuruddin ar-Raniri, Abdurrauf Singkel, dan beberapa lainnya. Untuk konteks Indonesia, seperti puisi karya Amir Hamzah, Abdul Hadi W.M., Taufiq Ismail, Kuntowijoyo, Emha Ainun Nadjib, D. Zawawi Imron, Hamid Jabbar, K.H.A. Mustofa Bisri, Ahmadun Y. Herfanda, Ajamuddin Tifani, dan beberapa lainnya.

Sekalipun perpuisian A. Mustofa Bisri adalah "sajak yang tak memperindah kata-kata", tetapi menjadi sajak yang indah justru sebab pembaca dihadapkan kepada "kesahajaan bahasa sajak", dan harus menggali makna secara intensif jika ingin sampai kepada makna batin sajak. Memaknai sajak A. Mustofa Bisri tidaklah sesederhana bentuk lahir (shurah) sajaknya. Pemaknaan akan sampai makna batin sajak jika pembaca mengetahui di mana simpul makna itu harus diurai: dari makna luar sajak yang tampaknya sempit, menuju makna dalam sajak sehingga mencapai makna dari makna-makna (ma'na alma’na). Hal ini dengan memberi interpretasi kepada tamsil (perbandingan, perumpamaan) metafisik sajak.

Selain sajak yang sudah dikutip, berikut ini termasuk sajak penting yang menjadi kunci bagi aktualisasi pengalaman mistik sekaligus pengalaman estetik puisi A. Mustofa Bisri. "Sajak Putih Buat Kekasih” (2001:32) adalah sajak kunci yang menggambarkan tingkatan tasawuf yang sering disebut A. Mustofa Bisri dalam sajaknya: khauf (takut) dan raja' (harap-harap cemas). Keduanya bukan sebab takut neraka dan berharap surga, melainkan demi ma'rifah (pengetahuan ketuhanan) yang berbuah mahabbah (cinta).

\section{Sajak Putih Buat Kekasih}

Aku datang pergi berharap dan kecewa

Berharap dan kecewa

Tapi biarlah

Kasih, 
Biar kebersamaan kita dengan demikian Abadi.

1998

"Kebersamaan" dengan Kekasih Yang Abadi, itulah yang menjadikan seluruh sajak di dalam buku puisi Gandrung karya A. Mustofa Bisri dalam situasi rindu (syauq) yang mengharu-biru. Tentu saja, rindu itu disebabkan oleh cinta yang tak terbilang jumlahnya ('isyq), sebagaimana hal ini digambarkan di dalam sajak dengan judul sama yaitu "Al'isyq" (2000:15-16). Akan tetapi, sebab antara makhluk dan penciptanya (khaliq) tidak memungkinkan di dalam satu dimensi ruang dan waktu, maka kerinduan seorang hamba ini seringkali berujung kepada "berharap" dan "kecewa" sebagaimana digambarkan dalam "Sajak Putih Buat Kekasih" tersebut. Atau, seperti dalam sajak "Hanien" (Yang Dirindukan), kerinduan itu hanya dijawab oleh sepi “.../malam ini/ lagi-lagi kau biarkan sepi/ mewakilimu." Namun, akhirnya sang Pencinta memperoleh jawaban dari usaha-usahanya melalui ibadah sosial dan ibadah ritualnya (sajak “Doa Pencinta 2", 2000:68-69) sekalipun:

Aku tak pantas tapi tetap memohon:

Ya Tuhan, anugerahilah aku

Cinta dan kasih sayangMu.

Ya Tuhan, Kau kabulkan karena kemurahanMu Atau Kau tolak permohonanku karena

Ketidakpantasanku

- Semoga Kau kabulkan aku tetap bersimpuh di depan pintuMu. Kemana lagi? Amin.

Sekalipun terus dan terus "berharap" sebab "kemana lagi" harapan itu dialamatkan kalau bukan kepada Yang Dicintai, yaitu Sang Kekasih (Allah). Bahkan, dengan "berharap dan kecewa" yang terus-menerus itulah justru 
"kebersamaan kita dengan demikian/ Abadi" (dengan A-kapital). "Keabadian" ini merupakan muara dari hidup.

\section{E. Simpulan}

Dari uraian sederhana ini sudah terang bahwa: pertama, ciri khas perpuisian A. Mustofa Bisri dalam buku Gandrung ini dalam mengekspresikan bahasanya "tidak memperindah kata-kata", seperti halnya dia ungkapkan dalam sajak "Aku Tak Akan Memperindah Kata-kata". Namun, "kesahajaan bahasa sajak" it u tidak berarti kemudian sajaknya jadi gamblang pemaknaannya sebab bagaimanapun puisinya begitu kaya simbol yang memiliki keterkaitan dengan alam pikir religius, bahkan mistisisme Islam (tasawuf). Oleh karenanya, untuk sampai kepada makna batin sajak, pembaca dituntut memiliki wawasan tentang alam pikir yang melatari penciptaan sajaknya. Alam pikir tersebut merupakan perpaduan pengalaman mistik dan pengalaman estetik, yang digambarkan melalui tamsil (perbandingan, perumpamaan) metafisik. Kedua, ada kesamaan tematik puisi A. Mustofa Bisri dengan puisi tradisi sufi yang bertema cinta dan kerinduan kepada Allah. Cinta dan kerinduan menjadi vision dari dinamika yang terus berputar.

\section{Daftar Pustaka}

Al-Qur'an dan Terjemahannya. Jakarta: Proyek Pengadaan Kitab Suci AlQur'an Departemen Agama RI., 1983/1984.

Al-Ataftazani, Abu al-Wafa' al-Ghanimi. 1997. Sufi dari Zaman ke Zaman. Terj. Ahmad Rofi' 'Utsmani. Bandung: Penerbit Pustaka.

Al-Ghazāii. 1996. Al-Asma' al-Husna: Rahasia Nama-nama Indah Allah. Terj. Ilyas Hasan. Bandung: Mizan, Cet. III.

Al-Hujwiri, Ibnu Usman. 2003. Kasyf al-Mahjub (Menyelami Samudera Tasawuf). Terj. Ahmad Afandi. Yogyakarta: Pustaka Sufi.

Al-Kharraz, Abu Sa'id. 2003. Jalan Cinta Menuju Allah. Yogyakarta: Pustaka Sufi.

Al-Qadir Jilani, Syekh Abd. 2006. The Secret of Secrets (Menyingkap Tabir Rahasia Ilahi Syekh Abd al-Qadir Jilani). Terj. Mudhofir Abdullah. Yogyakarta: Suluh Press.

Asyhari, Muhammad. 2006. Tafsir Cinta (Tebarkan Kebajikan dengan Spirit al-Qur'an). Jakarta: Hikmah (PT. Mizan Publika). 
Asy Syarif, Mahmud bin. 2003. Al-Qur'an Bertutur tentang Cinta, Terj. Yusuf Hanafi \& Abdul Fattah. Yogyakarta: Cahaya Hikmah.

Aceh, Abubakar. 1989. Pengantar Sejarah Sufi dan Tasawuf. Solo: Ramadhani. An-Nadwi, Abul Hasan. 1986. Jalaluddin Rumi Sufi Penyair Terbesar. Terj. M. Adib Bisri. Jakarta: Pustaka Firdaus.

Arabi, Ibn. 2004. Fusus al-Hikam, terj. Ahmad Sahidah dan Nurjannah Arianti. Yogyakarta: Pustaka Sufi.

Asfari MS dan Otto Soekatno Cr. 2002. Mahabbah Cinta Rabì'ah al-Adawiyah. Yogyakarta: Bentang.

Asy-Syarif, Mahmud bin. 2003. Al-Qur'an Bertutur tentang Cinta. Yogyakarta: Cahaya Hikmah.

Atho', Nafisul., dan Arif Fahrudin. Ed. 2003. Hermeneutika Transendental. Yogyakarta: Ircisod.

Bachri, Sutardji Calzoum.1981. O, Amuk, Kapak. Jakarta: Sinar Harapan.

Bisri, A. Mustofa. 1990. Ohoi (Kumpulan Puisi-puisi Balsem). Jakarta: Pustaka Firdaus.

. 1995. Rubayat Angin dan Rumput. Jakarta: Majalah Humor dan PT. Matra Multi Media, Cet.II.

. 1996. Wekwekwek (Sajak-sajak Bumi Langit). Surabaya: Risalah Gusti.

. 1997. Keindahan Tak Terbendung... Jakarta: Rumah Dongeng Indonesia. . 2000. Sajak-sajak Cinta Gandrung. Rembang: Al-Ibris. . 2002. Negeri Daging. Yogyakarta: Bentang. . 2003. Tadarus . Yogyakarta: Adicita Karya Nusa, Cet.II. . 2004. Mutiara-mutiara Benjol. Surabaya: Mata Air Publishing. . 2005. Pahlawan dan Tikus. Yogyakarta: Hikayat, Cet. II.

Bleicher, Josef. 2003. Hermeneutika Kontemporer, Terj. Ahmad Norma Permata. Yogyakarta: Fajar Pustaka.

Budiman, Kris. 1999. Kosa Semiotika. Yogyakarta: LKIS.

Burckhardt, Titus. 1976. Mengenal Ajaran Kaum Sufi. Terj. Azyumardi Azra. Jakarta: Pustaka Jaya.

Culler, Jonathan. 1983. The Persuit of Sign. London: Routledge \& Kegan Paul.

Chirzin, Muhammad. 2000. Menempuh Jalan Allah. Yogyakarta: Madani Pustaka. 
. 2003. Glosari al-Qur'an. Yogyakarta: Lazuardi.

Chittick, William C. 2000. Jalan Cinta Sang Sufi: Ajaran-ajaran Spiritual Rumi. Yogyakarta: Qalam, Cet. I.

. 2001. Hermeneutika al-Qur'an Ibnu al-”Araby. Yogyakarta:

Qalam.

. 2002. Tasawuf di Mata Kaum Sufi. Bandung: Mizan.

Damono, Sapardi Djoko. 1999. Sihir Rendra: Permainan Makna. Jakarta: Pustaka Firdaus.

Darma, Budi. 1984. Solilokui. Jakarta: Gramedia.

Ernst, Carl W. 2003. Ajaran dan Amaliyah Tasawuf. Terj. Ari Anwar. Yogyakarta: Pustaka Sufi.

Fromm, Erich. 1956. Terj. 2002. The Art of Loving. Jakarta: Fresh Book.

Faiz, Fakhruddin. 2002. Hermeneutika al-Qur'an. Yogyakarta: Qolam, Cet.III. Hadi W.M., Abdul. (Ed.). 1985. Sastra Sufi. Jakarta: Pustaka Firdaus. . (Ed.). 1985. Rumi Sufi dan Penyair. Bandung: Penerbit Pustaka. . 1995. Hamzah Fansuri: Risalah Tasawuf dan Puisi-puisinya. Bandung: Mizan. . 1999. Kembali ke Akar Kembali ke Sumber. Jakarta: Pustaka Firdaus.

Firdaus.

2000. Islam Cakrawala Estetik dan Budaya. Jakarta: Pustaka . 2001. Tasawuf yang Tertindas. Jakarta: Paramadina.

. 2004. Hermeneutika, Estetika, dan Religiusitas. Yogyakarta: Mahatari.

Hamka. 1984. Tasawuf Perkembangan dan Pemurniannya. Jakarta: Pustaka Panjimas.

. 1990. Tasawuf Modern. Jakarta: Pustaka Panjimas.

Iqbal, Muhammad. 1982. Membangun Kembali Pikiran Agama dalam Islam. Terj. Ali Audah, dkk. Jakarta: Tintamas.

James, William. 1984. The Varieties of Religious Experience. New York: Collier Macmillan Publishers.

Khamis, Muhammad Athiyah. 1993. Rabī'ah al-Adawiyah, Terj. Aliuddin Majhuddin dari Rabì'ah al-Adawiyah. Jakarta: Pustaka Firdaus.

Kuntowijoyo. 1991. Paradigma Islam. Bandung: Mizan.

Leaman, Oliver. 2005. Estetika Islam (Menafsirkan Seni dan Keindahan).

Bandung: Mizan. 
Mangunwijaya, Y.B. 1988. Sastra dan Religiositas. Yogyakarta: Kanisius. Murata, Sachiko. 1996. The Tao of Islam. Bandung: Mizan.

\& William C. Chittick. 2005. The Vision of Islam, Terj. Suharsono. Yogyakarta: Suluh Press.

Nadjib, Emha Ainun. 1983. 99 untuk Tuhanku. Bandung: Penerbit Pustaka.

Nasr, Seyyed Hossein. 1981. Warisan Sufi - Buku Pertama (Sufime Persia Klasik dari Permulaan hingga Rumi (700-1300). Yogyakarta: Pustaka Sufi.

et.al. Juni 2003. Warisan Sufi - Buku Pertama (Sufime Persia Abad Pertengahan (1150-1500). Yogyakarta: Pustaka Sufi.

. (Ed.). Oktober 2002. Ensiklopedi Tematis: Spiritualitas Islam (Fondasi). Bandung: Mizan.

Nasution, Harun. 1990. Filsafat dan Mistisisme dalam Islam. Jakarta: Bulan Bintang.

. 1995. Islam Rasional: Gagasan dan Pemikiran, Ed. Syaiful Muzani. Bandung: Mizan.

Nicholson, R.A. 2003. Tasawuf Cinta (Studi atas Tiga Sufi; Ibn Abi al-Khair, al-Jili, dan Ibn al-Faridh). Bandung: Mizan.

Ricoeur, Paul dalam John B. Thomson (Ed.). 1982. "Hermeneutics and the Human Sciences, Essays on Language, Action and Interpretation. Cambridge: Cambridge University.

. 2003. Filsafat Wacana: Membelah Makna dalam Anatomi Bahasa (The Interpretation Theory: Discourse and the Surplus of Meaning), Terj. Musnur Hery. Yogyakarta: Ircisod, Cet.II.

Riffaterre, Michael. 1978. Semiotics of Poetry. Bloomington: Indiana University Press.

Sangidu. 2003. Wachdatul Wujud: Polemik Pemikiran Sufistik antara Hamzah Fansuri dan Syamsuddin as-Samatrani. Yogyakarta: Gama Media.

Sastrowardoyo, Subagio. 1980. Sosok Pribadi dalam Sajak. Jakarta: Pustaka Jaya.

Schimmel, Annemarie. 1993. Akulah Angin Engkaulah Api. Bandung: Mizan. .1996. Rahasia Wajah Suci Ilahi. Bandung: Mizan. . 2003-a. Dimensi Mistik dalam Islam, cet. II. Jakarta: Pustaka Firdaus. . 2003-b. Sayap-sayap Jibril: Gagasan Religius Muhammad Iqbal. Yogyakarta: Lazuardi. 
IbdG' Jurnal Kebudayaan Islam

. 2005. Menyingkap Yang-Tersembunyi , terj. Saini K.M. Bandung: Mizan, Cet. I.

Sumaryono, E. 1999. Hermeneutik, Sebuah Metode Filsafat. Yogyakarta: Kanisius. 